Volume 11

Issue 3 Global Approaches to Atrocity

Prevention: Theory, Practice, and the State of

Article 13 the Field

3-2018

\title{
Book Review: Nation Building in Kurdistan: Memory, Genocide and Human Rights
}

Michael Gunter

Follow this and additional works at: https://digitalcommons.usf.edu/gsp

\section{Recommended Citation}

Gunter, Michael (2018) "Book Review: Nation Building in Kurdistan: Memory, Genocide and Human Rights," Genocide Studies and Prevention: An International Journal: Vol. 11: Iss. 3: 128-130.

DOI:

http://doi.org/10.5038/1911-9933.11.3.1568

Available at: https://digitalcommons.usf.edu/gsp/vol11/iss3/13

This Book Review is brought to you for free and open access by the Open Access Journals at Digital Commons @ University of South Florida. It has been accepted for inclusion in Genocide Studies and Prevention: An International Journal by an authorized editor of Digital Commons @ University of South Florida. For more information, please contact digitalcommons@usf.edu. 
Book Review: Nation Building in Kurdistan:Memory, Genocide and Human Rights

\author{
Michael M. Gunter \\ Tennessee Technological University \\ Cookeville, TN, USA
}

Nation Building in Kurdistan: Memory, Genocide and Human Rights

Mohammed Ihsan

London and New York, Routledge, 2017

178 Pages; Price: \$149.95 cloth

Reviewed by Michael M. Gunter

Tennessee Technological University

"Genocide is not a crime that happens in dark alleys."1 This pithy observation and over-all graceful analysis investigates five separate genocides committed by the Iraqi government of Saddam Hussein: the Arabization of historical Kurdish lands such as Kirkuk, the forced displacement of Faylee Kurds, the disappearance of eight thousand Barzanis in 1983, the Anfal campaign in 1988-89, and the chemical attack on Halabja in 1988. However, the post-Saddam "Iraqi federal governments showed no will to heal the wound caused by these events . . . with the exception of some ineffective legal decisions." 2 Thus, "justice has been very limited and has left the Kurds deprived of the compensation to which they were entitled, as well as feeling betrayed by Baghdad and its judicial system." ${ }^{3}$

As a former member of the Kurdistan Regional Government (KRG) - serving as Minister for Human Rights between 2001 and 2005 and later as Minister of Extra Regional Affairs and the KRG representative in Baghdad until May 2014 as well as being an academic holding a Ph.D. in international law from the University of London and another Ph.D. in Arab and Islamic Studies from the University of Exeter-Mohammed Ihsan is well-placed to write this account. His concluding table on page 134 portrays each of the five genocidal crimes, how vast the Iraqi agencies participating in them were, but how paltry were the number of final retributive verdicts. Thus,

many felt that his Shia enemies executed the ex-president [Saddam Hussein] before he was made to pay for crimes against the Kurds. This led most Kurds to think that justice had been hijacked by the tensions between Sunnis and Shias, leaving the Kurds without the possibility of seeing justice for the crimes committed against them. ${ }^{4}$

As a result, "any attempt to build a credible judicial system in Iraq was severely undermined by this event.." In also blaming the "many witnesses ... [and] the willingness of the greater part of society to do nothing" ${ }^{\prime}$ Ihsan further concludes that his analysis "has been able to demonstrate that the responsibilities lay far beyond the top of the regime." ${ }^{7}$

The author further takes issue with the many well-placed who solely blame the murderous insurgency that ravished Iraq after the U.S. victory [in 2003] on Paul Bremer's de-Ba'athification and disbanding of the Iraqi army, which put millions onto the streets with guns, but without jobs. He argues instead that "people who took part in the Arabization and genocide campaigns are still in the civil service and in the military structure of the government." ${ }^{8}$ Nevertheless, General

\footnotetext{
${ }^{1}$ Mohammed Ihsan, Nation Building in Kurdistan: Memory, Genocide and Human Rights (New York: Routledge, 2017$), 135$.

${ }^{2}$ Ibid., 4 .

${ }^{3}$ Ibid.

${ }^{4}$ Ibid., 134.

${ }^{5}$ Ibid., 21.

${ }^{6}$ Ibid., 135.

${ }^{7}$ Ibid., 135.

${ }^{8}$ Ibid., 35.

Michael Gunter, "Book Review: Nation Building in Kurdistan: Memory, Genocide and Human Rights" Genocide Studies and Prevention 11, 3 (2018): 128-130. $\odot 2018$ Genocide Studies and Prevention.

http://doi.org/10.5038/1911-9933.11.3.1568
} 
David Petraeus's reawakening gestures to the newly disenfranchised Sunnis temporarily stabilized Iraq until these lessons were tragically forgotten and ignored by Iraqi Prime Minister Nouri alMaliki's disastrous Shite government that helped birth another genocidal disaster known as ISIS. Ihsan emphasizes ISIS's origin from "such myopic politics" and this "dangerous mismanagement of post-Saddam Iraq . . . [and resulting] vacuum of power" that has led to the "now-inevitable disintegration of the country." 9

Ihsan further argues that this deplorable situation in part "stems from the Bush administration's ignorance of the history of Iraq and its multicultural population . . . [and] because the Bush administration never had a real postwar plan in place and it was merely looking for easy exit policies. ${ }^{10}$

As for Kirkuk, it

is about more than oil. ... For Kurds, Kirkuk symbolizes decades of forced displacement, the destruction of their homes and the occupation of their lands by Arab settlers. ... Kirkuk is key to peace settlement and the key to restoring justice to the [Kurdish] people. ${ }^{11}$

Illustrating his attempt to be fair to Kirkuk's non-Kurdish population, however, Ihsan warns that "the Kurdish claim over this land could trigger a new, deadly sectarian war,"12 one that this reviewer also feels might follow when ISIS is driven from Mosul and ethnic and sectarian boundaries reset. "The Kurds have to face reality.... Giving up the claims to Arab-majority towns, for example, in which Arab residents are not the consequence of Arabization, would be a first step to smoothing the negotiations with Baghdad."13

As for Halabja, "according to the Federation of American Scientists, this crime was, and still remains, the largest chemical weapons attack directed against a civilian-populated area in history." ${ }^{14}$ Thus, Ihsan concludes that "it is evident that Halabja constitutes the peak of the stateengineered genocide against the Kurds... [where] the regime distanced itself completely from an indifferent international community and international law."15

There are a few errors in the manuscript that should be flagged. The KRG first appeared after the election held on May 17, 1992, not "in November 1992."16 Unifying the "Peshmerga, or local militias, into the Unified Peshmerga Force under the direction of the Ministry of Peshmerga Affairs"17 is largely a myth since the Kurdistan Democratic Party (KDP) and Patriotic Union of Kurdistan (PUK) still actually control these forces. Jus cogens, not "jus gogens...is a basic concern, an independent principle, and a mandatory precept... in international law." 18 The author fails to explain why he thinks the ceasefire that ended the Gulf War against Saddam Hussein in February 1992 constituted "unjust terms."19 The domestic jurisdiction clause of the United Nations Charter is Article 2, paragraph 7, not "article 2, chapter 7."20 It is not clear which war the author means when he states that "in particular the war in Europe, paved the way for a new phase in Kurdish and Iraqi relations." ${ }^{21}$ "KRG Prime Minister Nechir Van Barzani"22 almost sounds like a Dutch name. The correct spelling, of course,

\footnotetext{
${ }^{9}$ Ibid., 25, 137, 118.

${ }^{10}$ Ibid., 32.

${ }^{11}$ Ibid., 31.

${ }^{12}$ Ibid., 39.

${ }^{13}$ Ibid., 129.

${ }^{14}$ Ibid., 97.

${ }^{15}$ Ibid., 112.

${ }^{16}$ Ibid., 6.

${ }^{17}$ Ibid., 13.

${ }^{18}$ Ibid., 16.

${ }^{19}$ Ibid., 17.

${ }^{20}$ Ibid., 17.

${ }^{21}$ Ibid., 19.

${ }^{22}$ Ibid., 35.
} 
is Nechirvan. Endnote twenty-four on page forty-one confuses Gareth Stansfield as an editor of the book Crisis in Kirkuk when actually he is the co-author along with the correctly listed Liam Anderson. The well-known Kurdologist Ofra Bengio is a woman, and therefore it is not "his book"23 that is referred to. If "killing members of a group is considered a basic element in the recognition of the crime of genocide," ${ }^{24}$ how does this differ from regular war?

Ihsan includes fourteen helpful maps, a list of abbreviations, five appendices each dealing with the five case studies of genocide detailed in the book, a short index, and a longer useful bibliography of secondary sources. However, one wonders why the author includes eleven separate works by the Armenian genocide scholar Vahakn N. Dadrian, dealing mostly with the Armenians, yet does not even mention the more apropos studies by Joost Hiltermann and Choman Hardi on the Iraqi Kurdish genocide. Nevertheless, Ihsan's jargon-free, reader-friendly study is recommended for scholars and practitioners as well as the intelligent lay public.

${ }^{23}$ Ibid., 79.

${ }^{24}$ Ibid., 105. 